\title{
Level of Heat Shock Protein 70 in the Brain after Seizure Induction in Normo- and Hyperglycemic rats: Relationship to Neurotransmitters Level
}

\author{
Abeer El-Emam Dief, Hala M. Abou-Heif \\ Department of physiology, Alexandria faculty of Medicine
}

\begin{abstract}
Although heat shock protein 70 (Hsp70) has been suggested to be a stress marker or to play a protective role in brain injury, the relevance of its expression in epilepsy and hyperglycemia is unclear. The aim of this study was to evaluate the level of Hsp70 in the rat hippocampus following pilocarpine induced seizure in normo- and hyperglycemic rat and its relation to glutamate and $\gamma$ amino-butyric acid (GABA) level. This study was carried out on 40 adult male albino rats divided into two main groups 20 rats per each; Group I: induction of seizures in normal rats; Ia: 10 control rats were injected with intraperitoneal (i.p.) saline. Ib: 10 rats were injected with pilocarpine (310-320mg/kg,ip) for seizure induction. Group II: induction of seizures in diabetic rats; 20 rats were rendered diabetic for one month by the injection of streptozotocin. Then they were subdivided into 2 subgroups; Group II a: 10 diabetic rats were injected with i.p. saline. Group II b: 10 diabetic rats were injected with i.p. pilocarpine. Development of diabetes was confirmed by measuring blood glucose levels in blood samples taken from tail vein. At the end of experimental period rats were sacrificed and the hippocampi were bilaterally dissected and handled to estimate levels of Hsp70, glutamate and GABA concentration. The results revealed significant increase in Hsp70 concentration in hippocampus after experimental seizures, Hyperglycemia alone was not associated with significant change in Hsp70 level in group II a compared to control. No significant difference in Hsp 70 level was found between hyperglycemic rats with and without seizure induction. Levels of glutamate and GABA were not changed significantly after pilocarpine administration. Hyperglycemia followed by seizure induction was associated with significant increase in glutamate and decrease in GABA level. On the other hand, hyperglycemia alone failed to exert any significant change in NT levels. The current study therefore, suggested that Hsp70 could play a role in neuroprotection during an epileptogenic state as evidenced by low scores of seizure in rats and levels of NT; in addition, Hyperglycemia is associated with impairment of Hsp70 expression; therefore, the neurons were more vulnerable to the damaging effect of pilocarpine as showed in severe seizure attacks and significant changes in NT level.
\end{abstract}

Keywords: heat shock protein70, hippocampus, seizures, hyperglycemia, glutamate, $\gamma$ amino-butyric acid.

Abbreviations: Hsp70; heat shock protein70, GABA; $\gamma$ amino-butyric acid, STZ; streptozotocin, HPLC-ECD; high performance liquid chromatographyelectrochemical detector, NT; neurotransmitter, 


\section{INTRODUCTION}

The heat shock proteins (HSPs) are a family of proteins originally identified as being up-regulated in response to elevated temperature, but now a wide range of cellular stresses such as hypoxia, ischemia, glutamate, and heavy metals have been shown to induce HSPs. HSPs consist of a family of highly conserved proteins grouped according to their molecular size: the high molecular mass proteins $(110,90,70-72$, and 55-60 kDa) and the small HSPs, which include HSP27, ubiquitin, $\alpha \mathrm{A}-$ and $\alpha \mathrm{B}-$ crystallin. ${ }^{(1)}$ HSPs function differently at various physiological conditions. Under unstressed conditions, Hsp serve as molecular chaperone assisting in the process of protein synthesis, while in stress conditions, Hsp assist in the maintenance of cellular integrity and viability. ${ }^{(2)}$

The $70 \mathrm{kD}$ family of stress proteins is one of the most extensively studied. The mechanism of protection with Hsp70 has largely been believed to be related to its chaperone functions, leading to prevention of protein malfolding and aggregation. ${ }^{(3)}$ In addition, Hsp70 can improve cell survival via antiapoptotic mechanism. ${ }^{(4)}$ Hsp70 may also alter other proteins or genes known to be involved in inflammatory response. Various studies indicate that Hsp70 has an anti-inflammatory effect as it decreases the release of inflammatory mediators. ${ }^{(3)}$ In the central nervous system, heat shock protein (Hsp) synthesis is induced in a variety of pathologic states, including cerebral ischemia, neurodegenerative disease, excitotoxin exposure and trauma. ${ }^{(5,6)}$
Although 70-KDa heat shock protein has been thought to protect cells by preserving tertiary protein structure and preventing protein aggregation, its neuroprotective role still remains unclear. ${ }^{(4,7,8)}$

Imbalance between inhibitory gamma-amino-butyric acid (GABA) and excitatory glutamate neurotransmitters as well as alterations of ion channels, may be involved in pathogenesis in epilepsy. Excitotoxicity due to excessive glutaminergic transmission seems to be an important factor in pathogenesis of epilepsy. However, experiments in vivo have shown that large increases in the extracellular levels of endogenous glutamate do not necessarily induce neurodegeneration or seizures. $^{(9,10)}$

Diabetes mellitus is associated with impairment of endogenous tissue defense mechanisms and vulnerability of tissues to various types of stress. Since long-lasting hyperglycemia causes modification of cellular proteins, it is possible that expression of molecular chaperones as Hsp may be altered during the course of diabetes. ${ }^{(11,12)}$

One of the most widely used models for studying the pathological changes of human temporal lobe epilepsy is pilocarpine (muscarinic agonist) induced seizures in rats. Intracerebral or systemic administration of pilocarpine selectively elaborates epileptiform activity in the limbic structures accompanied by motor limbic seizures, limbic status epilepticus and widespread brain damage. ${ }^{(13,14,15)}$ Pilocarpine induced seizures were thought to be produced by muscarinic activation which 
enhance postsynaptic response because of potassium channel closure. ${ }^{(16)}$ In addition, changes in the anatomic organization of the temporal lobe could be attributed to pilocarpine administration. Brain lesions in the olfactory cortex, hippocampus, amygdale, and thalamus are also observed in pilocarpine model. ${ }^{(17)}$

Therefore, the aim of this study was to evaluate the level of Hsp70 in the rat hippocampus following pilocarpine induced seizure in normoand hyperglycemic rat and its relation to glutamate and GABA level.

\section{MATERIAL \& METHODS}

\section{Animals}

Forty adult male albino rats weighing 150-180 g, were utilized in this study. They were housed in cages under standard laboratory conditions (temperature $23 \pm 2{ }^{\circ} \mathrm{C}$ ) and lightcontrolled (lights on from 7.00am to $7.00 \mathrm{pm})$

They were given food and water ad libitum. All the protocols followed in this study were approved by the University Committee of Medical Ethics

They were divided into two main experimental groups, 20 rats per each:

\section{-Group I: induction of seizures in} normal rats;

Ia: 10 control rats were injected with intraperitoneal saline.

Ib: 10 rats were injected with pilocarpine for seizure induction as described below.

Group II: induction of seizures in diabetic rats;

20 rats were rendered diabetic by the injection of streptozotocin, as described below. Then they were subdivided into 2 subgroups;

Group II a: 10 diabetic rats were injected with intraperitoneal (ip) saline.

Group II b: 10 diabetic rats were injected with ip pilocarpine 30 days after STZ administration.

\section{Seizure induction in rats:}

Rats were pretreated with i.p. injection of atropine sulphate $(1 \mathrm{mg} / \mathrm{kg})$ an anticholinergic agent, 20 minutes prior to induction of seizures by cholinergic agents pilocarpine (310-320mg/kg,ip, BoheringerGermany) to abolish the undesirable peripheral cholinergic effects. ${ }^{(14)}$ Control rats were given an equal volume of saline. Rats were observed for behavioral evidence of seizures. Only rats displaying behavioral manifestation of seizures were included in the study. Behavioral seizures were scored previously by Racine $^{(\mathbf{1 8})}$ scale modified by Pinel and Rovner $^{(19)} 0=$ immobility, $1=$ facial automatisms, 2 = head myoclonus, 3 $=$ forelimb myoclonus , $4=$ rearing, 5 $=$ falling, $6=$ more than three falls, 7 $=$ wild running, $8=$ tonic-clonic seizures.

About $20 \%$ of pilocarpine treated rats died after induction of seizures. Seizures were terminated by diazepam (10 mg/kg,ip) as required depending on the response of the rat to pilocarpine injection. ${ }^{(20)}$ 6-8 $\mathrm{h}$ following pilocarpine administration, blood was withdrawn from abdominal aorta under ether anesthesia; brains were removed quickly, dissected for removal of the hippocampi bilaterally and frozen on dry ice. The dissected brain were weighed, homogenized and stored for further assessment. 
Induction of diabetes in rats

Diabetes mellitus was induced in rats by a single intraperitoneal injection of STZ (Sigma, Germany) freshly dissolved in cold $0.1 \mathrm{M}$ citrate buffer, $\mathrm{pH} 4.5$ at a dose of $45 \mathrm{mg} / \mathrm{kg}$ BW. ${ }^{(21)}$ Glucose (5\%) was given for two days After STZ injection. (22)

Two days after STZ treatment, development of diabetes was confirmed by measuring blood glucose levels in blood samples taken from tail vein. Blood glucose level was estimated weekly till the end of the experimental period (one month). ${ }^{(12)}$ Rats with non-fasting blood glucose levels of $300 \mathrm{mg} / \mathrm{dl}$ or higher were considered to be diabetic. ${ }^{(23)}$

\section{Hsp70 by ELISA:}

Heat shock protein 70 in rat brain extract was measured using Assay Design Stressgen Hsp70 ELISA which is quantitative sandwich immunoassay. ${ }^{(24)}$

Sample preparation:

Approximately $0.5 \mathrm{~cm}^{3}$ piece of hippocampus was homogenized in 1 $\mathrm{ml}$ of extraction buffer provided by the kit supplemented with $1 \mu \mathrm{g} / \mathrm{ml}$ aprotinin (a protease inhibitor). After centrifugation at $21.000 \mathrm{~g}$ for 10 minutes, the supernatant was used to estimate protein by Lowry method ${ }^{(25)}$ the rest was diluted by the sample diluent provided by the kit in the ration of 1:4 and used in the assay procedure. Hsp70was expressed as $\mathrm{ng} / \mathrm{mg}$ protein.

GABA and glutamate level by high performance liquid chromatography - Electrochemical detector (HPLC- ECD).

Tissue preparation

The brain was rapidly removed from the cranium and dissected out on an ice-cold plate as previously described $^{(26)}$. Hippocampi were removed, weighed and placed in microcentrifuge tubes, which contained $1 \mathrm{ml}$ of chilled homogenisation buffer $(0.1 \mathrm{M}$ citric acid, $\quad 0.1 \mathrm{M}$ sodium dihydrogen phosphate monohydrate, $5.6 \mathrm{mM}$ octane sulfonic acid, 10 m EDTA in $10 \%(\mathrm{v} / \mathrm{v})$ methanol solution, $\mathrm{pH} 2.8$ with $4 \mathrm{M} \mathrm{NAOH}$ ). Each sample was centrifuged at 14,000 rpm for $15 \mathrm{~min}$ at $4 \mathrm{C}^{\circ}$ and the supernatant stored at $-80 C^{\circ}$ until derivatisation for GABA/glutamate analysis. ${ }^{(27)}$

Small aliphatic amino acids, such as glutamate and $\gamma$-amino-butyric acid (GABA) are not naturally electroactive and do not possess fluorescent or strong UV absorbance characteristics, rendering their analysis by HPLC problematic. Precolumn derivatisation can overcome this drawback and a variety of reagents have been used for this purpose. ${ }^{(28)}$ One of the most commonly used derivatising agents is $o$-phthalaldehyde (OPA) which reacts with primary amines in the presence of a thiol and generates derivatives which are both electroactive and fluorescent. ${ }^{(29)}$ This procedure determined the level of GABA and glutamate following its derivatization with OPA by the modified method of Allison et al. ${ }^{(30)}$

GABA and glutamate were identified by their characteristic retention times as determined by standard injections which were run at regular intervals during sample analysis. Sample peak heights were measured and compared with standard injections in order to quantify the amino acids.

\section{Statistical analysis}

Data are presented as mean + S.D. Data analysis was performed using 
SPSS version 10 computer software. ANOVA (F) test followed by least significant difference (LSD) was performed to compare variables between different corresponding groups. Significance was set at $\mathrm{P}<0.05$.

\section{RESULTS}

Pilocarpine injection induced behavioral seizure in all rats; however, seizure severity was variable among the groups. In normo-glycemic rats, seizure score was varied from 2 to 3 . However, hyperglycemic rats showed severe behavioral changes with high seizure scores 4 to 6 . To end or limit behavioral seizures induced by pilocarpine, diazepam $(10 \mathrm{mg} / \mathrm{kg}$, i.p. $)$ was administered.

Blood glucose level (BGL) was increased significantly after STZ injection in groups IIa and $\mathrm{IIb}$ compared to the other groups.

Hsp70 was significantly increased after induction of seizure by pilocarpine in group $\mathrm{Ib}$, its level was significantly high compared to the other groups. Hyperglycemia alone was not associated with significant change in Hsp70 level in group IIa compared to control. No significant difference in Hsp70 was found between hyperglycemic rats with and without seizure induction. (Table I) (Fig.1a, b)

There was no significant change in glutamate level after pilocarpine administration in group Ib. However, pilocarpine administration in hyperglycemic rats was associated with significant increase in glutamate level in group IIb compared to the other groups. Hyperglycemia alone was not associated with change in glutamate concentration in group IIa compared to control.

Similarly, GABA concentration was not changed significantly after seizure induction in group $\mathrm{Ib}$ compared to control. Hyperglycemic rats, on the other hand, showed significant decrease in GABA level after pilocarpine administration in group IIb compared to the control group. Hyperglycemia alone was not associated with significant change in GABA concentration in group IIa compared to control. (Table II) (Fig.2a,b)

Table I: Blood glucose level (BGL) in $\mathrm{mg} / \mathrm{dl}$ and heat shock protein 70 (Hsp 70) in $\mathrm{ng} / \mathrm{mg}$ protein in the studied groups.

\begin{tabular}{|l|c|c|c|c|c|c|}
\hline \multirow{2}{*}{ Parameter } & \multicolumn{2}{|c|}{ Group I } & \multicolumn{2}{c|}{ Group II } & \multirow{2}{*}{ F } & \multirow{2}{*}{ p } \\
\cline { 2 - 6 } & Group Ia & Group Ib & Group II a & Group II b & & \\
\hline BGL (mg/dl) & & & & & & \\
Range & $80-112$ & $80-112$ & $400-500$ & $400-450$ & & \\
mean \pm S.D & $95.4 \pm 10.7^{\mathbf{a}}$ & $94.2 \pm 10.8^{\mathbf{a}}$ & $444 \pm 31.3^{\mathbf{b}}$ & $430 \pm 15.8^{\mathbf{b}}$ & 107.16 & $0.0001^{*}$ \\
\hline $\begin{array}{l}\text { Hsp70 (ng/mg } \\
\text { protein) }\end{array}$ & & & & & & \\
Range & $2.45-3.59$ & $4.13-6.83$ & $1.6-4.7$ & $2.01-3.9$ & & \\
mean \pm S.D & $2.94 \pm 0.5^{\mathbf{a}}$ & $5.84 \pm 1.2^{\mathbf{b}}$ & $2.833 \pm 0.9^{\mathbf{a}}$ & $2.89 \pm 0.6^{\mathbf{a}}$ & 32.83 & $0.0001^{*}$ \\
\hline
\end{tabular}

Same letter means no significant difference.

* Means significant. 
Table II: Brain glutamate ( $\mu \mathrm{g} / \mathrm{g}$ tissue) and $\gamma$-amino-butyric acid (GABA) $(\mu \mathrm{g} / \mathrm{g}$ tissue) levels in the studied groups.

\begin{tabular}{|c|c|c|c|c|c|c|}
\hline \multirow{2}{*}{ Parameters } & \multicolumn{2}{|c|}{ Group I } & \multicolumn{2}{|c|}{ Group II } & \multirow{2}{*}{$\mathbf{F}$} & \multirow{2}{*}{$\mathbf{p}$} \\
\hline & Group Ia & Group Ib & Group IIa & Group IIb & & \\
\hline $\begin{array}{l}\text { Glutamate } \\
\text { ( } \mu \mathrm{g} / \mathrm{g} \text { tissue })\end{array}$ & & & & & & \\
\hline $\begin{array}{l}\text { Range } \\
\text { mean } \pm \text { S.D }\end{array}$ & $\begin{array}{c}1850-1891 \\
1878.2 \pm 13.8^{\mathbf{a}}\end{array}$ & $\begin{array}{c}1800-1920 \\
1886 \pm 32.3^{\mathrm{a}}\end{array}$ & $\begin{array}{c}1865-1890 \\
1878.3 \pm 9.2^{\mathrm{a}}\end{array}$ & $\begin{array}{c}1880-2000 \\
1942.4 \pm 46.9^{b}\end{array}$ & 10.93 & $0.0021 *$ \\
\hline $\begin{array}{l}\text { GABA }(\mu \mathrm{g} / \mathrm{g} \\
\text { tissue })\end{array}$ & & & & & & \\
\hline $\begin{array}{l}\text { Range } \\
\text { mean } \pm \text { S.D }\end{array}$ & $\begin{array}{l}220-239 \\
233 \pm 6.7^{\mathbf{a}}\end{array}$ & $\begin{array}{c}210-240 \\
224.6 \pm 10.8^{\mathbf{a}}\end{array}$ & $\begin{array}{c}220-241 \\
231.6 \pm 6.1^{\mathrm{a}}\end{array}$ & $\begin{array}{c}185-201 \\
193.2 \pm 6.2^{b}\end{array}$ & 58.72 & $0.00001^{*}$ \\
\hline
\end{tabular}

Same letter means no significant difference.

* Means significant.
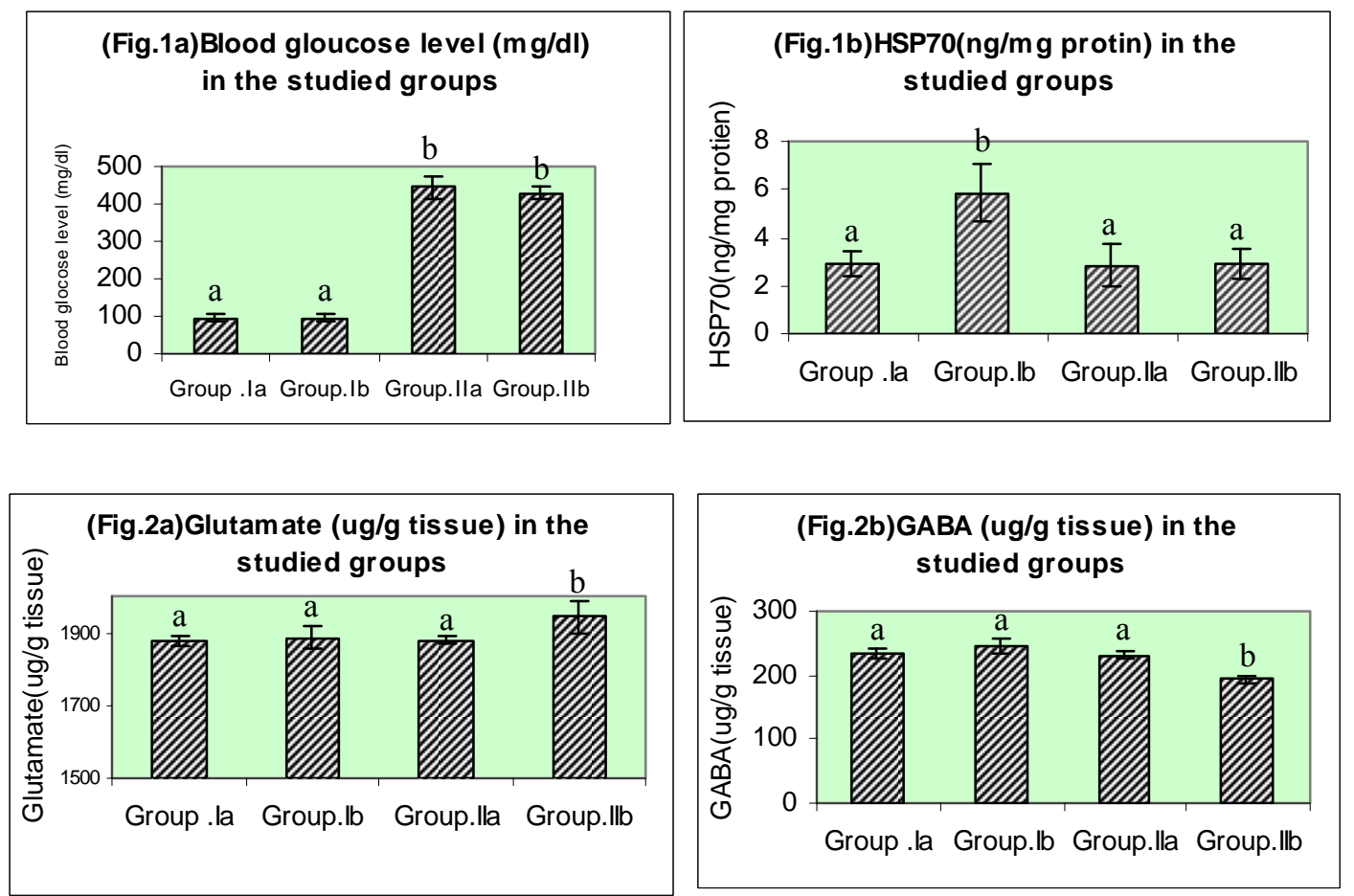

The same letter meanss no significant difference. 


\section{DISCUSSION}

Heat shock proteins (HSPs) are the major molecular chaperones whose function is to mediate the proper folding of other proteins and to ensure that these proteins maintain their native conformations during conditions of stress. In addition, HSPs are required for protein trafficking to target organelles and to facilitate the transfer of misfolded proteins to the proteasome for degradation ${ }^{(\mathbf{3 1 , 8})}$ Neurons are particularly vulnerable to the detrimental effects of misfolded and/or aggregated proteins because they cannot dilute potentially toxic species through cell division; hence, misfolded proteins accumulate in neurons during stress. ${ }^{(32)}$ However, the protective role of $\mathrm{Hsp} 70$ against various cerebral insults has been debated. ${ }^{(\mathbf{8})}$

The current study had demonstrated that pilocarpine administration for seizure induction resulted in increased level of Hsp70 in the hippocampus within 6 hours of pilocarpine application. The induction of Hsp70 in the present study was reflected by lower behavioural manifestations of seizures according to Racine and Pinel \& Rovner scale ${ }^{(\mathbf{1 8 , 1 9 )}}$ indicating significant protection. The protective role of Hsp70 was reported by several researchers. ${ }^{(\mathbf{3 3}, 34)}$ Yenari et al. ${ }^{(\mathbf{3 3})}$ had studied Hsp70 expression in a model of experimental epilepsy; they demonstrated that Hsp70 was expressed diffusely within the brain particularly within the cortical and hippocampal neurons. Protein expression has been observed to be especially prominent within brain regions known to be resistant to injury, whereas less expression was seen in degenerating neurons. They assumed that Hsp70 may be responsible for the observed resistance. In contrast, other data suggested that Hsp70 is expressed in vulnerable cell populations or is expressed regardless of the fate of the cell. Therefore, Hsp70 may be capable of rescuing injured cells provided that protein has been translated. ${ }^{(34)}$

Moreover, Yang et $\mathrm{al}^{(\mathbf{8})}$ had reported that Hsp70 was not detected in dying neurons in rat hippocampus after Kainic acid induced seizures. Therefore, they concluded that Hsp70 expression is induced in vulnerable neurons at the beginning of epileptogenesis, whereas, the failure for its detection at late stage is mainly due to increased extent of neuronal death. Hsp70 expression can be a useful indicator of the localization of stressed neurons.

The protection offered by Hsp70 may be mediated by one or more of the many activities ascribed to Hsp70, including refolding denatured proteins and preventing unfolded and damaged proteins from aggregating, or by a direct anti-apoptotic and antiinflammatory mechanism. ${ }^{(7)}$ The protection offered by Hsp70 was evidenced in this study by the occurrence of low seizure score as well as non significant changes in glutamate or GABA level.

However, Hsp70 is not protective in all instances. Fink et al. ${ }^{(35)}$ showed that Hsp70 overexpression protected cultured hippocampal neurons from severe heat shock but failed to protect against direct application of glutamate or mitochondrial toxins. Wagstaff et 
al. ${ }^{(36)}$ showed that Hsp70 overexpression protected cultured peripheral neurons from thermal and stimulated ischemia, but not apoptotic stimuli. These results suggest that Hsp70 protect against some but not all kinds of central nervous system injury, and that the protective effect may be related to the nature and severity of the insults as well as the type and age of the cell.

Alteration of neurotransmitter (NT) levels has been attributable to the development of excitotoxicity and seizures. Glutamate excitotoxicity has been implicated as a factor in neuronal injury following seizures. Current results demonstrated mild increase in glutamate after seizure induction which was insignificant compared to the control. Therefore, Hsp70 can protect against excitotoxic insult. This finding was in accordance with Tanaka et al. ${ }^{(37)}$ who reported that elevated level of extracellular glutamate has not been demonstrated in the brain during seizure in experimental animals.

Imbalances between excitatory and inhibitory synaptic transmission in key brain areas such as hippocampus are implicated in the pathophysiology of temporal lobe epilepsy (TLE), in which fast synaptic excitatory neurotransmission is mediated via activation of ionotropic glutamate receptors like NMDA receptors. Khan et $\mathrm{al}^{\mathbf{( 3 8 )}}$ revealed a decrease in glutamate receptor binding in the hippocampus of epileptic rats, as compared with control rats, without any change in affinity. This decreased receptor binding in the hippocampus is suggested to be due to the hyperexcitability caused by glutamate release in the initiation of seizures. Glutamate is supposed to exert its excitatory action via the NMDA receptors. However, in temporal lobe epilepsy, NMDA mRNA gene expression specifically in hippocampus was found to be increased, decreased, or unchanged. ${ }^{(39,40)}$

Induction of diabetes using STZ resulted in significant modifications of cellular proteins and may be followed by structural alteration of these proteins. Therefore, the expression of molecular chaperones, which are required to maintain the integrity of protein structure, may be altered during the course of diabetes with impairment in the cytoprotective ability of diabetic rat. ${ }^{(\mathbf{1 2})}$

The current work demonstrated significant decrease of Hsp70 expression in STZ treated rats. Exposure of diabetic rats to another stressful injury as seizure was not associated with significant increase in the expression of Hsp70. Therefore, presences of diabetes suppressed the expression of Hsp70 in the brain and make the neurons more vulnerable to injury as observed by severe attacks of seizure in hyperglycemic rats treated with pilocarpine, as well as significant alteration in NT level.

This finding was supported by several authors, who reported decreased Hsp level in animal models of diabetes, in human subjects with diabetes and in people with just insulin resistance. They attributed the development of diabetic complications to low Hsp70. Therefore, therapy has been developed which directed at raising Hsp70 to limit the development of diabetic complications. ${ }^{(\mathbf{4 1 , 4 2})}$ It was reported that hyperglycemia was 
associated with reduction of $\mathrm{Hsp} 70$ expression in the liver but not in the brain, pancrease and adrenal gland following administration of STZ. ${ }^{(12)}$ Atalay et al. ${ }^{(11)}$ had evidenced that diabetes decreased overall levels of Hsp72 in heart, liver, and vastus lateralis muscle. On the other hand, Muranyi et al. ${ }^{(\mathbf{3})}$ reported that hyperglycemic ischemia upregulated the expressions of Hsp70, Hsp90A and Hsp90B; therefore, they concluded that hyperglycemia associated brain damage is not mediated by the suppression of Hsp70.

Chen et $\mathrm{al}^{(\mathbf{4})}{ }^{\mathrm{C}}$ had evidenced that insulin could increase the expression of Hsp60 in cardiac muscle, and insulin deficiency led to reduced expression of Hsp60 in myocardium of STZ induced diabetic rats. They suggested that insulin deficiency or inadequate insulin action may be the underlying mechanism leading to downregulation of Hsp60 in cardiac muscle, which contributes to decreased IGF-1 receptor signaling and reduced myocardial protection.

Therefore, further studies are needed to clarify the involvement of stress proteins in diabetic disease.

$\mathrm{DM}$, on the other hand, can modify the level of free amino acids and accumulation of NT. The current study showed increase in glutamate and decrease in GABA concentration in hippocampaus of hyperglycemic rats treated with pilocarpine, such changes in the NT level was associated with high scores of seizures after pilocarpine administration. This finding was supported by $\mathrm{Li}$ et al. ${ }^{(45)}$, who studied the effect of cerebral ischemia as stressful insult in hyperglycemic rats and they reported an increased accumulation of extracellular glutamate in the neocortex submitted to hyperglycemic ischemia, which was correlated with the cell damage observed. Guyot et $\mathrm{al}^{(46)}$, on the other hand, had reported that, chronic state of hyperglycemia results in reduction in extracellular brain glutamate levels during ischemia/reperfusion and therefore does not appear to be responsible for the increased neuronal damage seen in diabetic stroke. Moreover, chronic hyperglycemia causes decreased extracellular gamma-aminobutyric acid levels, therefore, loss of the inhibitory effects of this neurotransmitter, could contribute to the increased damage observed in hyperglycemic stroke.

On the other hand, in the current study, hyperglycemia alone was not associated with significant change in glutamate or GABA level. This observation was in accordance with Duarte et al, ${ }^{(47)}$ who reported that DM has no effect on GABA and glutamate

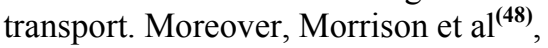
reported that streptozotocin-induced diabetes (type 1 diabetes model) does not change the transport mechanism or the receptor sensitivity to GABA.

This finding was partly disagreed by Vilchis and Salceda ${ }^{(49)}$ who reported an increase in GABA uptake, whereas glutamate uptake remained unaffected in diabetic rat retina.

The controversial observations reported by some authors on alterations in brain amino acid transport using diabetic rats may be related to the diabetic model or to the experimental approach used. Diabetes is associated with decrease in the 
synaptosomal transmembrane gradient and decrease in ATP. The decrease in ATP production is a hallmark of a disturbance in glucose metabolism, which could be partially balanced by the use of endogenous brain substrates, such as glutamate and fatty acids. ${ }^{\text {(50) }}$ Synaptosomal uptake of neurotransmitters is an energydependent process that requires the integrity of membrane systems and functional mitochondria. ${ }^{(47)}$

In conclusion, the results showed that Hsp70 is increased in rat hippocampus following administration of pilocarpine and occurrence of experimental seizures which is considered stressful to the neurons, Hsp70 can induce protection of the neurons as evidenced by low seizure score and non significant alteration in glutamate and GABA level. Hyperglycemia is associated with impairment of Hsp70 expression; therefore, the neurons were more vulnerable to the damaging effect of pilocarpine as showed in severe seizure attacks and significant changes in NT level.

\section{Acknowledgements:}

This work was supported by the Central Lab in Faculty of pharmacy, Alexandria University by providing technical assistance in HPLC for GABA and glutamate estimation.

\section{REFERENCES}

1. Akbar MT, Lundberg AM, Liu K, Vidyadaran S, Wells KE, Dolatshad H, Wynn S, Wells DJ, Latchman DS, de Belleroche J (2003). The Neuroprotective Effects of Heat Shock Protein 27 Overexpression in Transgenic Animals against Kainate-induced Seizures and Hippocampal Cell Death. J Biol Chem; 278: 19956-65.

2. Mayer MP, Bukau B (2005). Hsp70 chaperones: cellular functions and molecular mechanisms. Cell Mol Life Sci; 62: 670-84.

3. Yenari MA, Liu J, Zheng $Z$, Vexler ZS, Lee JE, Giffaed RG (2005). Antiapoptotic and antiinflammatory mechanisms of heat shock protein protection. Ann N Y Acad Sci; 1053: 74-83.

4. Matsumori Y, Hong SM, Aoyama K, Fan Y, Kayama T, Sheldon RA, Vexler ZS, Ferriero DM, Weinstein PR, Liu J (2005). Hsp70 overexpression sequesters AIF and reduces neonatal hypoxic/ ischemic brain injury. $\mathrm{J}$ Cereb Blood Flow Metab; 25: 899-910.

5. Mayer RJ (2003). From neurodegeneration to neurohomeostasis: the role of ubiquitin. Drug News Perspect; 16: 103-8.

6. Calabrese V, Scapagnini G, Ravagna A, Giuffrida Stella AM, Butterfield DA (2002). Molecular chaperones and their roles in neural cell differentiation. Dev Neurosci; 24: 1-13.

7. Giffard RG, Xu L, Zhao H, Carrico W, Ouyang Y, Qiao Y, Sapolsky R, Steinberg G, Hu B, Yenari MA (2004). Chaperones, protein aggragation, and brain protection from hypoxic/ischemic injury. J Exp Biol; 207: 3213-20.

8. Yang $\mathrm{T}$, Hsu $\mathrm{C}$, Liao $\mathrm{W}$, Chuang J (2008). Heat shock protein expression in epilepsy suggests stress rather than 
protection. Acta Neuropathol; 115: 219-30.

9. Peña F, Tapia $R$ (2000). Seizures and neurodegeneration induced by 4-aminopyridine in rat hippocampus in vivo: role of glutamate and GABA-mediated neurotransmission and of ion channels. Neuroscience; 101: 547-61.

10. Goodkin HP, Yeh JL, Kapur J (2005). Status epilepticus increases the intracellular accumulation of GABAA receptors. J Neurosci; 25 (23): 5511-20

11. Atalay $M$, Oksala $N$, Laaksonen D, Khanna S, Nakao C, Lappalainen J, Roy S, Hänninen O, Sen CK (2004). Exercise training modulates heat shock protein response in diabetic rats. J Appl Physiol ; 97: 605-11.

12. Yamagishi $\mathbf{N}$, Nakayama $K$, Wakatsuki T, Hatayama $T$ (2001). Characteristic changes of stress protein expression in streptozotocin-induced diabetic rats. Life Sciences; 69: 2603-9.

13. Turski WA, Cavalheiro EA, Schwarz M, Czuczwar SJ, Kleinrok Z, Turski L (1983). Limbic seizures produced by pilocarpine in rats: behavioural, electroencephalographic and neuropathological study. Behav Brain Res ; 9(3):315-35.

14. Turski WA (2000). Pilocarpineinduced seizures in rodents--17 years on. Pol J Pharmacol; 52(1):63-514.

15. Cavalheiro EA, Santos NF, Priel MR (1996). The pilocarpine model of epilepsy in mice. Epilepsia; 37: 1015-9.
16. Sayin U, Rutecki PA (1997). Effects of pilocarpine on paired pulse inhibition in the $\mathrm{CA} 3$ region of the rat hippocampus. Brain Res; 758: 136-42

17. Klitgaard H, Matagne A, Vanneste-Goemaere J, Margineanu DG (2002). Pilocarpine-induced epileptogenesis in the rat: impact of initial duration of status epilepticus on electrophysiological and neuropathological alterations. Epilepsy Res; 51:93-107.

18. Racine RJ (1972). Modification of seizure activity by electrical stimulation: II. Motor seizure. Electroencephalogr Clin Neurophysiol; 32:281-94.

19. Pinel JP, Rovner LI (1978). Experimental epileptogenesis: kindling induced epilepsy in rats. Exp Neurol; 58:190-202.

20. Jankowsky JL, Patterson PH (1999). Differential regulation of cytokine expression following pilocarpine induced seizures. Exp Neurol; 159: 333-46.

21. Krishna KM, Annapurna A, Gopal GS, Chalam CR, Madan K, Kumar VK, Prakash GJ (2005). Partial reversal by rutin and quercetin of impaired cardiac function in streptozotocininduced diabetic rats. Can J Physiol Pharmacol;83: 343-55.

22. Yoruk M, Kanter M, Meral I, Agaoglu $Z$ (2004). Localization of glycogen in the placenta and fetal and maternal liver of cadmium exposed diabetic pregnant rats. Biol Trace Elem Res; 96: 217-26.

23. Sahu A, Sninsky CA, Phelps CP, Dube MG, Kalra PS, Kalra 
SP (1992). Neuropeptide Y release from the paraventricular nucleus increases in association with hyperphagia in streptozotocin-induced diabetic rats. Endocrinology; 131(6): 2979-85.

24. Gray CC, Amrani M, Yacoub MH (1999). Heat stress proteins and myocardial protection: experimental model or potential clinical tool? Int J Biochem Cell Biol; 31(5): 559-73.

25. Lowry OH, Rosbrough NJ, Farr AI, Randall RJ (1951). Protein measurement with folin phenol reagent. J Biol Chem; 193: 265-75.

26. Harkin A, Connor TJ, Mulrooney J, Kelly JP, Leonard BE (2001). Prior exposure to methylenedioxyamphetamine (MDA) induces serotonergic loss and changes in spontaneous exploratory and amphetamine-induced behaviours in rats. Life Sci; 68:1367-82.

27. Shah AJ, Crespi F, Heidbreder C (2002). Amino acid neurotransmitters: separation approaches and diagnostic value. J Chromatogr B Analyt Technol Biomed Life Sci; 781:151-63.

28. Shah AJ, de Biasi V, Taylor SG, Roberts C, Hemmati P, Munton R, West A, Routledge C, Camilleri P (1999). Development of a protocol for the automated analysis of amino acids in brain tissue samples and microdialysates. J Chromatogr B Biomed Sci Appl;735:133-40.

29. Nussbaum MA, Przedwiecki JE, Staerk DU, Lunte SM, Riley CM (1992).
Electrochemical characteristics of amino acids and peptides derivatized with naphthalene-2,3dicarboxaldehyde: $\mathrm{pH}$ effects and differences in oxidation potentials. Anal Chem; 64 (11): 1259-63.

30. Allison LA, Mayer GS, Shoup RE (1984). O-Pthalaldehyde derivatives of amino acids highspeed liquid chromatography/ electrochemistr. Anal Chem;56: 1089-96.

31. Chen S, Brown IR (2007). Neuronal expression of constitutive heat shock proteins: implications for neurodegenerative diseases. Cell Stress Chaperones; 12(1): 51-58.

32. Muchowski PJ, Wacker JL (2005). Modulation of neurodegeneration by molecular chaperones. Nat Rev Neurosci; 6:11-22.

33. Yenari MA (2002). Heat shock protein and neuroprotection. Adv Exp Med Biol; 513: 281-99.

34. Massa SM, Swanson RA, Sharp FR (1996). The stress gene response in brain. Cerebrovasc Brain Metab Rev; 8(2): 95-158.

35. Fink SL, Chang LK, Ho DY, Sapolsky RM (1997). Defective herpes simplex virus vectors expressing the rat brain stressinducible heat shock protein 72 protect cultured neurons from severe heat shock. J Neurochem; 68: 961-69.

36. Wagstaff MJ, Smith J, CollacoMoraes Y, de Belleroche JS, Voellmy R, Coffin RS, Latchman DS (1998). Delivery of a constitutively active form of the heat shock factor using a virus 
vector protects neuronal cells from thermal or ischaemic stress but not from apoptosis. Eur J Neurosci; 10(11):3343-50

37. Tanaka K, Graham SH, Simon RP (1996). The role of excitatory neurotransmitters in seizureinduced neuronal injury in rats. Brain Research ; 737:59-63.

38. Khan R, Krishnakumar A, Paulose CS (2008). Decreased glutamate receptor binding and NMDA R1 gene expression in hippocampus of pilocarpineinduced epileptic rats: Neuroprotective role of Bacopa monnieri extract. Epilepsy Behav; 12 :54-60

39. McDonald JW, Garofalo EA, Hood T, Sackellares JC, Gilman S, McKeever PE, Troncoso JC, Johnston MV (1991). Altered excitatory and inhibitory amino acid receptor binding in hippocampus of patients with temporal lobe epilepsy. Ann Neurol; 29: 52941.

40. Geddes JW, Cahan LD, Cooper SM, Kim RC, Choi BH, Cotman CW (1990). Altered distribution of excitatory amino acid receptors in temporal lobe epilepsy. Exp Neurol; 108:21420.

41. Hooper PL (2003). Diabetes, nitric oxide and heat shock proteins. Diabetes Care; 26: 9512.

42. Hooper PL, Hooper JJ (2005). Loss of defense against stress: diabetes and heat shock proteins. Diabetes Technology \& Theraputics; 7(1): 204-8.
43. Muranyi M, He QP, Fong KS, Li PA (2005). Induction of heat shock proteins by hyperglycemic cerebral ischemia. Brain Res Mol Brain Res; 139(1):80-7.

44. Chen HS, Shan YX, Yang TU, Lin H, Chen J, Lin S, Wang PH (2005). Insulin Deficiency Downregulated Heat Shock Protein 60 and IGF-1 Receptor Signaling in Diabetic Myocardium. Diabetes; 54:17581.

45. Li PA, Shuaib A, Miyashita $H$, He QP, Siesjö BK, Warner DS (2000). Hyperglycemia enhances extracellular glutamate accumulation in rats subjected to forebrain ischemia. Stroke; 31:183-92.

46. Guyot LL, Diaz FG, O'Regan MH, Song D, Phillis JW (2001). The effect of streptozotocininduced diabetes on the release of excitotoxic and other amino acids from the ischemic rat cerebral cortex. Neurosurgery; 48(2): 38590.

47. Duarte AI, Santos MS, Seic R, Oliveira CR (2004). Oxidative Stress Affects Synaptosomal $\gamma$ Aminobutyric Acid and Glutamate Transport in Diabetic Rats The Role of Insulin. Diabetes; 53:2110-16.

48. Morrison PD, Mackinnon MW, Bartrup JT, Skett PG, Stone TW (1992). Changes in adenosine sensitivity in the hippocampus of rats with streptozotocin induced diabetes. Br J Pharmacol; 105:1004-8.

49. Vilchis C, Salceda $R$ (1996). Effect of diabetes on levels and uptake of putative amino acid 
neurotransmitters in rat retina and retinal pigment epithelium. Neurochem Res; 21:1167-71.

50. Hoyer $S$ (2002). The brain insulin signal transduction system and sporadic (type II) Alzheimer disease: an update. $\mathrm{J}$ Neural Transm; 109:341-60.

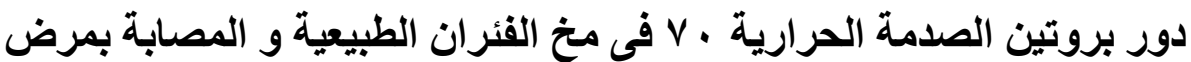

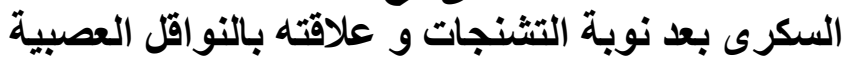$$
\text { عبير الإمام ضبف ، هالة محمود /ابر/هبم /بو هيف }
$$

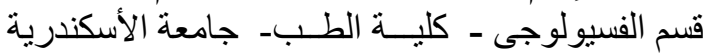

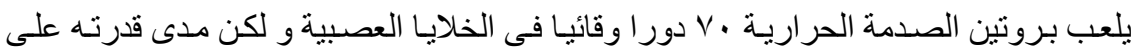

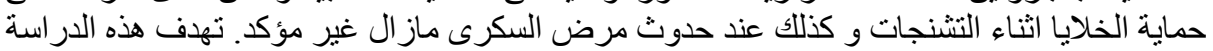

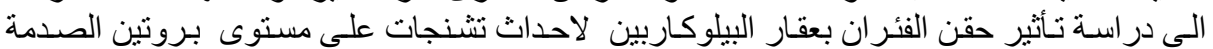

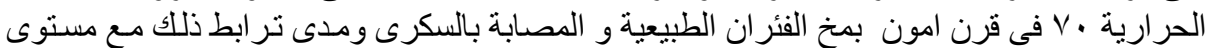

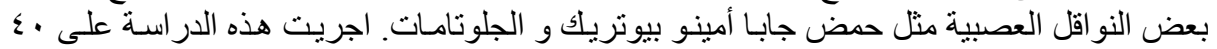

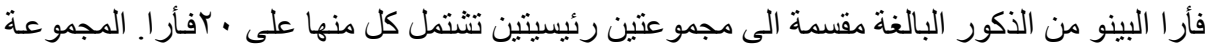

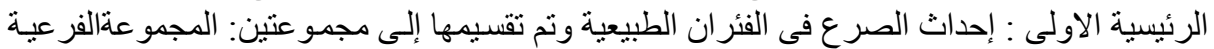

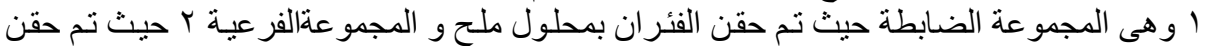

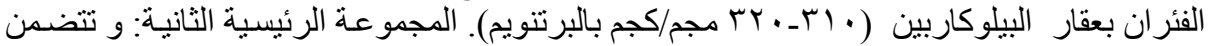

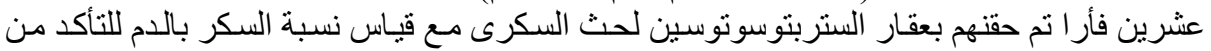

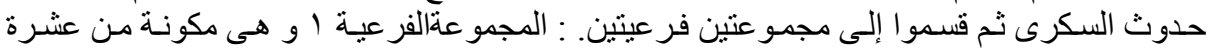

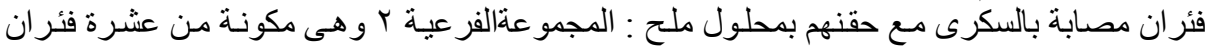

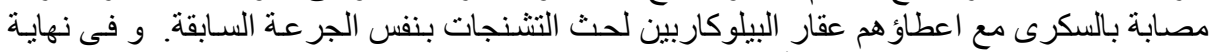

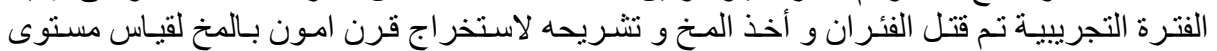

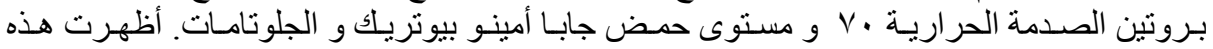

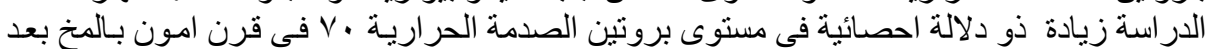

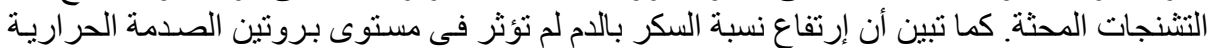

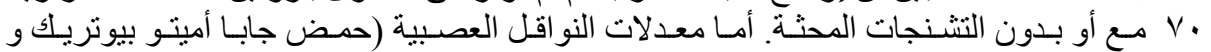

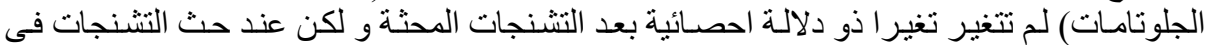

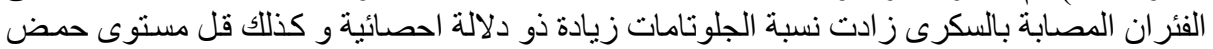

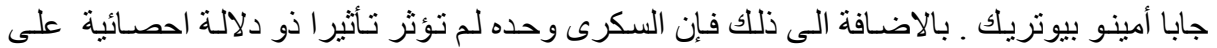

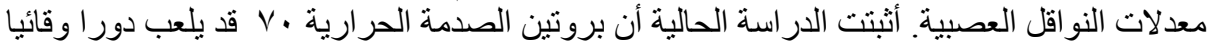

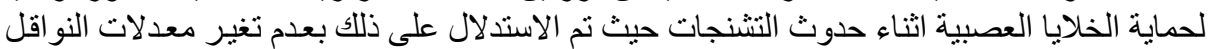

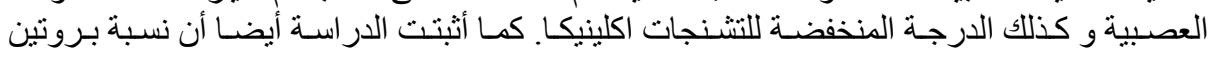

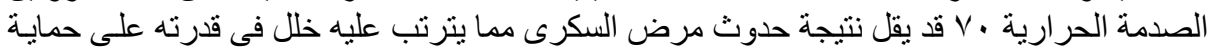 \\ الخلايا العصبية.
}

